\title{
He Was Like No Other \\ (In Memoriam Levon Mikhailovich Chailakhyan)
}

DOI: $10.1134 / \mathrm{S} 0006350910030267$

It is already a year that Levon Mikhailovich Chailakhyan, Corresponding Member of RAS, is not among us. One can rarely meet a man who would take so critically and ironically his own significance and the significance of all he has done in physiology and biophysics. Yet there was quite something to be proud of. He published more than 450 works in leading Russian and international journals, was awarded the medal of the All-Russia Physiological Society named after I.P. Pavlov, was a member of the European Academy of Sciences, but there's too much to enumerate.

One of the first Chailakhyan's biophysical works considered a kind of cardiac arrhythmia (Wenckebach period). The next series of works was devoted to experimental and theoretical analysis of complex excitable structures such as cardiac syncytium and nerve cell dendrites. Together with S.A. Kovalev, V.V. Smolyaninov, Yu.I. Arshavskii, and M.B. Berkinblit he has shown that the specific features of the spread of excitation depend not only on the parameters of cell membranes but also on the geometry of the excitable structure. Many of his works were connected with the role of highly permeable cell-cell contacts in the function of non-excitable tissues. In particular, it has been shown that such contacts are important in embryogenesis.

On the whole, the works in embryology came to be perhaps the most interesting in Chailakhyan's research. Development of novel methods of cell fusion brought about a great achievement. Chailakhyan together with B.N. Veprintsev, T.A. Sviridova, and V.A. Nikitin were the first to have cloned a mammal, Masha the Mouse. The report of this feat was published in 1987, ten years before the famous Dolly the Sheep.

Apart of scientific work, Levon Mikhailovich paid much attention to pedagogical activity. For many years he has been reading lectures at the Chair of Physiology of the Biological Faculty and a special course on the physiology of excitable tissues at the Chair of Biophysics of the Physical Faculty of MSU, he was Dean of the Training Center of Physiology and Biophysics at the Pushchino State University.

The scientific interests of Levon Mikhailovich were not limited to purely laboratory research. He thought much over the general problems of brain function. A result of these cogitations was the monograph "Sources of the Origin of Mentality or Consciousness" (1992).

Levon Mikhailovich was a kind and joyful man, who deserved to be loved; he has left so much after him that we shall be learning from him for a long time. And it is not only his science, it is his attitude to friends and opponents, to nature, sports, feasts. He was a man of remarkable integrity, he could forgive anything, except errors in experiments.

L.M. Chailakhyan was Director Organizer of the Institute of Theoretical and Experimental Biophysics, RAS in Pushchino, and then worked as its Director for 11 years more. Try to imagine a man heading one of the key Institutes of the Academy for so long and having made no enemies - yet this was so. At the age of eighty he was younger at heart than many who have not turned fifty.

All his conscious life Levon Mikhailovich toiled to the glory of our physiology and biophysics. Friends and colleagues will always remember this fascinating main-scientist, educator, and organizer of science.

G.R. Ivanitsky
and A.V. Kulikov 